\title{
Состояние и перспективы селекции зернофуражных культур в условиях Северного Зауралья
}

Фомина М.Н.

Научно-исследовательский институт сельского хозяйства Северного Зауралья филиал Федерального исследовательского иентра ТюмНЦ СО РАН, пос. Московский, Тюменская область, Россия

e-mail:maria_f72@mail.ru

Работы по созданию сортов ярового овса и ячменя в условиях Северного Зауралья до конца 1970-х гг. прошлого столетия практически не велись. Первые сорта овса (Тюменский 82, Вагай), созданные в данном регионе, были получены на опорном пункте СибНИИСХ при НИИСХ Северного Зауралья. В 1981 г. в НИИСХ Северного Зауралья была создана лаборатория селекции зерновых и кормовых культур. Самостоятельная лаборатория по селекции зернофуражных культур была организована в 1995 г. За истекший период времени было создано и передано в государственное сортоиспытание 15 сортов овса и 9 сортов ячменя. В настоящее время в Государственный реестр селекционных достижений включено 5 сортов овса (Мегион, Талисман, Отрада, Фома, Тюменский голозерный) и 2 сорта ячменя (Абалак, Зенит). Потенциальная урожайность пленчатых сортов овса 6.08.0 т/га, голозерного - 4.0 т/га, ячменя - 6.5-7.5 т/га. Сорта высокопластичны и рекомендованы для использования в ряде регионов РФ (Мегион - 4, 10; Талисман, Фома - 10, 11, 12; Отрада - 9, 10, 12; Тюменский голозерный - 4, 7, 9, 10, 11; Абалак - 4, 10, 11; Зенит - 4, 12). Селекция овса в Северном Зауралье ведется в двух направлениях: создание сортов зернового типа и зерноукосного. Решается также задача по созданию сортов универсального использования (на зерно и зеленый корм). Таким сортом, внесенным в Государственный реестр, является Талисман. С 2018 г. государственное сортоиспытание проходит новый сорт универсального использования - Тоболяк. За годы изучения в условиях Северного Зауралья (питомник конкурсного сортоиспытания 2014-2017 гг.) он превзошел стандартный сорт Талисман по урожаю зеленой массы на 5.3 т/га, по сбору сухого вещества на 1.3 т/га, по урожаю зерна на 1.0 т/га. Селекционные работы по ячменю направлены главным образом на получение новых сортов кормового и пищевого использования, также ведется отбор низкобелковых форм, перспективных для пивоваренной промышленности. В государственное сортоиспытание передан высокопродуктивный сорт ячменя Кудесник, у которого содержание белка за годы испытания на заключительном этапе селекционного процесса (2015-2018 гг.) составило 9.58-11.68\%. 